\title{
Sustainable Democracy and the Paradox of the Arab Spring: The Egypt Experience.
}

\author{
Etemike Laz
}

\begin{abstract}
The Arab spring began with an uprising in Tunisia and subsequently spread to Egypt, Bahrain, Morocco, Libya, Yemen and Syria. The protest has been referred to as the Arab spring and for others the Arab democratic revolution. Despite the substantial variants of the revolt it explains a component of a great collective shift from long tenure and authoritarian rule. The aftermath of the transition from authoritarianism to democracy should have been the establishment of independent democratic structures. This is the only way that a sustainable democracy can be guaranteed. This is where such factors as religion (Islam), monarchies, military and fundamentalism, come to be a crucial factor in analysing and assessing the success or failure of the Arab democratic revolution. This paper is of the opinion that a sustainable democracy within the Arab world cannot be guaranteed, in view of the above contesting variables for political/state power and influence. Each of these variables is not only anti democratic but present a contradiction in democracy. Egypt experience is instructive. What is thus needed is a frame work to manage and structure these diversities toward providing sustainable democratic political institutions that are in consonance with democratic tenets without radically changing the norms, values and nuances of the Arab society
\end{abstract}

Key words: Arab Spring, Democratization, Democracy, Islam, Fundamentalism.

* Department of Political Science, Delta State University,P.M.B 1 Abraka, Delta State. Nigeria. Email etemikelaz@yahoo.com 


\section{Etemike Laz}

\section{Introduction}

Islam provides governance in the Arab countries. It is the prevailing religion in the Arab world, mixed with pockets of other faiths and its role in Arab politics varies from state to state. These variations not withstanding Islam provides governance in the Arab countries. The starting point for this work would be an examination of the nature and character of the pre-Arab spring era and its relation with the concept of government and governance. Consequently, the problems of transition are multiple which have to do with structure, modality, function, role and concept. Arab states or its political societies have been suppressed for decades by authoritarian regimes using Islam. There is a compelling need to rebuild or restructure the Arab political society to accommodate the vital tenets of liberal democracy. The implication would be to restructure the ruler cum servant relationship to a positive promotion of liberal democratic values, reflected in less emphasis on the promotion of Islamic extremism and its authoritarian concept.

It is trite to state that this is not a critique as it were on the merit or demerit of Islamic religion. It is rather an attempt to analyse the democratic credentials of some Arab countries as it concern sustainable democracy. Sustainable democracy according to Sorenson ${ }^{1}$ requires the establishment of independent political institutions that dispense justice independent of regime leadership which referee political disputes in a manner widely accepted and which provide outlets for diverse political views without censorship.

This work therefore doubt the possibility and probability of the success of the Arab spring in the wake of contrasting view between the Islamic system and the western accepted tenets of democracy. $\mathrm{May}^{2}$ aptly capture the scepticism of some scholars when he posit that it is possible we are seeing an Arab spring, a democratic awakening, upspring that will bring freedom to societies that have known only oppression. But it is equally possible that one form of oppression will simply replace another as in the case of what happened in Eastern Europe in 1989 or Iran in 1979. More capturing is the view of Rubeiz $^{3}$ that it is difficult to predict how religion will mix with politics in feature-oriented Arab societies. He observed that extreme Muslim group tend to thrive in freedom starved societies. Police state he noted allows fanatic groups to exist and organise in return for being silenced and passive. Hence when reform takes place, fanatic religious parties are likely to lose the self-serving protection of the state.

It is in this light that this work like others intends to reflect on certain already raised pertinent questions, can Muslim parties participate in building a renewed society which is also faithful to Islamic tradition? Can the power of the state be separated from the power of the mosque? What would be the role or faith of fanatical groups in democratic setting? And what would be the role of the military in building a democratic culture in an Islamic state in which it had enjoyed privileges and patronages politically and economically

\section{Islamic Governments}

There has been the argument that Islam does not pose any obstacle to democratization. Proponents of this argument claim that two-thirds of the world's Muslims live under democratic systems. Such democracies as Turkey, India, Albania, Jordan, and Pakistan were cited as examples. The opposing argument however explains that this assumption could be misleading. This is because each of the countries mentioned run different strands of political Islam and perhaps a semblance of democracy. 
They further argued that the emphases on shariah and the Quran are manifestations of anti-democratic norms. For these reasons political Islam should be distinguished when assessing the prospects for democratization in the Arab States. The claim has been that Islamic societies have failed to develop distinctive political institutions. This is as a result of the dominating role of Islam thus, creating a powerful group of religious leaders who relegate the secular authority and institutions to the background.

Consequently, over the years the people have become fatalistic and easy to dominate and manipulate McCormick ${ }^{4}$ (2007) thus observed that one of the effects of the division is the variety of political structures and situations in the various Islamic countries. They vary from the absolute monarchies of Saudi Arabia to the constitutional monarchies of Jordan and Bahrain, and from Islamic republic's of Pakistan and Iran to legally secular states of Algeria, Egypt, Syris and Pakistan. Even in the legally secular states Islam has been a central issue in politics.

For instance, Pakistan under Newaz Sharif as Prime Minister had decided that shariah of no one sect should be adopted. This was in recognition of the existing of different interpretations of the Shariah by the different Muslim groups. Though the Prime Minister accepted the supremacy of the Quran, no legislation was to be made contrary to the fundamental Quranic teachings. At the same instance Pakistan would not adopt any rules and regulations which spring from laws as if they were legislative instructions from God( see Kalifatul Masih ${ }^{5}$,). The paradox is as to how the varied interpretations of the various Islamic sects can be harmonized in a manner that would support democratic norms.

Sorenson ${ }^{6}$ noted that persistent rule was a hallmark of many Arab regimes. For instance, the al-Saud family has governed Saudi Arabia since 1932, Sultan Qaboos ruled Oman since 1971, the Alodte family reigned in Morocco since 1956, the Assad family controlled Syria since 1970, and Muamar Qaddafi ruled Libya since 1969. Most of the longevity cases are said to have quashed leftist and Islamic movements, negotiated to keep the military from launching periodic coups by buying off soldiers with powerful positions in the government and the economy. In fact patronage kept many Arab leaders afloat.

Sorenson ${ }^{7}$ explain that strong Arab rulers prolonged their stay in power by capturing existing institutions or creating new ones to serve the interests of themselves and their parties, usually to distribute patronage to regime supporters. He went on to assert that because of these patronages and Potemkin village-like electoral structures, the kind of political institutions upon which democracy must be constructed are lacking. Such as independent judiciaries, civil societies that are independent and electoral mechanism designed to facilitate elections instead of stealing them. This situation is most prevalent in most Arab states that are ruled by the military. Arab militaries, it is said often became praetorian guards that deposed monarchs and Sultans on a regular basis and replaced them with those of their liking and in some cases impose themselves on the people. Hence the military in postindependent periods emerged as major part of the state capacity, participating and controlling, to some extent the distribution and redistribution of national resources.

It is pertinent to note that since the 1970s there has been Islamic resurgences. Remarkable about this resurgence is that there was a reassertion of Islam. Both government and opposition movements have turned to Islam to enhance their authority and muster support. A remarkable factor responsible for the division and variety in the type of government in Islamic states is the doctrinal divisions. The two major divisions or sect is the shiah and the sunni. The shiah believe they are the true Muslims in the model of Mohammed and that he was semi-divine, while the sunni believe that Mohammed was an ordinary human being, for which they do not believe in religious leaders on earth. The division can be further compounded with the further divisions of the sects. For instance, within the shi'ah Islam there are 34 sects whose interpretation of shariah differs each from the other. Within sunni Islam there are at 


\section{Etemike Laz}

least 34 sects whose interpretation also differ ${ }^{8}$. The question is whose voices should be heard? A body legislates and some scholars of Islam insist that the law was against the fundamental principles of Islam.

\section{Democracy and Democratization}

Democratization has been described as an authocthonous and authocentric process of social restructuring in consonance with the prevailing social values, ethnic norms and nuaces of the generality of the society ${ }^{9}$. It is thus expected that a true democratic environment encourages self realization which enables the individual to be lifted above the narrow circle of his egoism and broadens his interest. The individual is said to become interested in his country and develop a sense of national responsibility. It is in a sense a function of the expansion of society's structures and values. It can also be interpreted to mean developing such structures and values that are internal and encompassing. This view tally with Oyorvbaire' $\mathrm{s}^{10}$ definition of democratization as an encompassing mass consciousness and participation. Burnell $^{11}$ aptly explain it thus, that democratization means far more than the introduction of free and fair elections, especially in societies where institutional development in the party system and civil society has been repressed. He pointed out that democratization usually involve processes of cultural and social change involving attitude, norms and values as well as institutional building.

However, Dahl ${ }^{12}$, Raphael, and Nwokeji ${ }^{13}$ all argued that there is no definition of democracy, hence no theory of democracy. It is in this light that Onoge ${ }^{14}$ rhetorically stated that the discussion now is not democracy, but what form of democracy should there be. Hence substantial literature and discourse on democracy and democratization is characterized by the meaning of democracy. Despite the views expressed by the authors mentioned above and Burnell's earlier assertion, Burnell ${ }^{15}$ insist that democracy has a continuum in which democratic tenets are expressed in different societies. Democratic tenets which in Burnell's opinion are generally considered a more desirable version of democracy include, electoral democracy with respect for civil liberties, political right of groups and individuals, constitutionalism and the rule of law. The focus mostly is on an election that gives the people a chance to determine who should rule.

The concept of electoral democracy however has a strenuous critic in Rouseau's idea of democracy. According to Rousseau ${ }^{16}$ cited in Heywood democracy was the means through which human being could achieve freedom or autonomy in the sense of obedience to a law one prescribes to oneself. Heywood explains Rousseau's ${ }^{17}$ position of freedom or autonomy as when citizens participate directly and continuously in shaping the life of community. This idea in Heywood's ${ }^{18}$ view moves well beyond the conventional notion of electoral democracy and offers support for the more radical idea of direct democracy. In Rousseau's view therefore such a democracy require not only political equality but a relatively high level of economic equality. Hence he proposed that no citizen shall be rich enough to buy another and none so poor as to be forced to sell himself ${ }^{19}$. The concept of liberal democracy has nonetheless, in the contemporary era gained variety of meanings. For instance, Gauba ${ }^{20}$ represent democracy as a combination of free-market economy with universal adult franchise. In his view this is distinct from other forms of political system by certain principles and characteristics, such as its procedural institutional arrangements. Gauba ${ }^{21}$ listed government by consent, public accountability, majority rule, recognition of minority rights and constitutional government as the broad principles of liberal democracy. 
Gauba $^{22}$ highlighted the following as mechanism of liberal democracy;

More than one political party freely competing for political power

-That there should be more than one political party freely competing for political power

-Political offices not confined to any privileged class

-Periodic elections based on universal adult franchise

-Protection of civil liberties and

-Independence of the judiciary

Consequently, democratization and the promotion of democracy refer to a range of different strategies, forms, and modalities directed at supporting movement towards (Liberal) democracy. Despite the varied forms of democracy examined the basic discussion is to place this as a template in accessing the nature of the Arab governments and their possibility for a transition to liberal democracy. Perhaps it is necessary to recall Onoge's ${ }^{23}$ question as to the form of democracy that should be envisaged for the Arab countries.

\section{Democracy and Arab Autocracy}

Brzezinski $^{24}$ a former U.S National Security Adviser observed that in earlier time, it was easier to control one million people than to physically kill one million people; today, it is infinitely easier to kill one million people than to control one million people. Scholars have developed numerous hypotheses for why some countries are nondemocratic. One outstanding factor is religion and in this case Islam. It has been argued that Islam and the tribal, patrilineal nature of Arab culture are antithetical to democratic norms. A brief history will suffice. By the late $19^{\text {th }}$ century, the Arab countries were under Shariah law, that produced autonomous governing organizations. The Arab countries have since then retained authoritarian political structure which has prevented democratic institution from taking root. Again in post-colonial period Arab nationalism became the dominant movement in independent Arab countries that experienced colonial rule. Arab nationalism thus facilitated a new class of autocrats to power in the form of modern Arab dictators. Good enough the new form of Arab nationalist advocated for political modernity.

A number of factors and sources influenced post independent Arab society; they include contact with Europeans, the narratives of modernizing Islamist thinkers, Christians and Arabs from the Eastern Mediterranean ${ }^{25}$. Despite the rise of Arab nationalism Islam nonetheless maintained political and cultural hold over the Arab countries. However the decline of Arab nationalism saw the emergence of political Islam. Consequently repressive regimes and radical Islamists emerged, which subsequently saw the birth of violent movements such as the Muslim Brotherhood movements in such places as Syria, Jordan and Egypt. For instance in the 1980s the Muslim Brotherhood virtually declared war on the ruling Ba' ath regime while in Algeria in 1992 there was a violent clash between the Algerian armed forces and the Islamist movements that claimed over a 100,000 lives. In Egypt the ruling regime banned the Muslim Brotherhood and either assassinated or executed some of its key leaders ${ }^{26}$. The general response by the autocratic Arab regimes against the violent Islamist Movements was to considerably limit their participation in politics. This response is not to be interpreted as a move by the Arab regimes against Islam, for there was considerable support in the Arab countries for Islam to play a greater role 


\section{Etemike Laz}

in politics. However the disagreement was the extent of such a role and the survival of the autocratic regimes in the face of Islamic fundamentalism. We have hitherto noted the diverse sects in Islam which at the same instance explain the diverse interpretations of the Quaran and the Sharia. This situation has produced radical and moderate Islamists. Even at that the moderat Islamist have the tendency to become violent or radical while contesting for influence in government.

Coppedge $^{27}$ pointed to the ways authoritarian regimes in the Middle East have manipulated culture, and Islam to bolster their claim to rule. This view is strengthened by the rentier state theory. The rentier state argument state that the dependence of governments on oil rents over taxation has lessened their accountability to their people. It has allowed leaders to fund large, centralized, corrupt states with repressive security apparatuses. Coppedge ${ }^{28}$ thus observe that countries in the Middle East have experienced only various forms of authoritarian regime, be they monarchic, colonial, one partynationalist or personalistic dictatorship. He concludes that their legitimacy formulae have rarely rested on democratic principles.

In assessing and analyzing the level and prospect of democracy in the various Arab states the different strands of political Islam must be distinguished. It is in this light that Rubeiz ${ }^{29}$ stated that it is difficult to predict how religion will mix with politics in future-oriented Arab societies. Arab monarchies such as Saudi Arabia took it upon themselves to block democratic transitions, fearing a sweeping away of autocratic regimes in the Arab world if any were to fall to democratic rule. Religion as it were has provided the needed weapon to justify their right to the throne. For instance the al-Saud family justifies its right to rule largely through its adherence to the "Wahhabi" understanding of Sunni Islam $^{30}$.

Saudi Arabia being a Sunni regime apart from encouraging solidarity among the Sunni Kings and monarchs has in conjunction with the Gulf Cooperation Council ( the King club of the Gulf Arab Countries) sent security forces to quell anti-regime demonstrations in Bahrain during the Arab spring. Most striking is the fact that Saudi Arabia has as a whole worked against any Islamic group that profess a different understanding of Islamic law that world challenge the understanding that justifiers absolute monarchy. Hence Saudi Arabia inserted itself as a defender of the Sunni dominated Gulf countries ${ }^{31}$. While there has been a consistent demand for an Islamic sharia state based on the principle of God's rule, which incidentally is not in line with democracy, post-Islamists tend to accommodate some aspects of democracy such as, pluralism, women's rights, youth concerns and social development with adherence to religion ${ }^{32}$.

The deft question which becomes a paradox is whether democracy can strive in the jungle of diverse interpretation of Islam and religious fundamentalism in the Arab world. It is trite to note that certain Arab countries over time adopted the name Islamic Republic. The term Islamic Republic has come to mean several things, some of which are contradictory to others. One of such meaning is a state under a particular theocratic form of government. It is also seen as purely an Islamic caliphate, and secular nationalism and republicanism. It is the conception that in an Islamic republic the panel code of the state is required to be compatible with some laws of Sharia, and the state may not be a monarchy as many middle Eastern States are. In fact many argue that an Islamic Republic strikes a Middle path between a completely secular and a theocratic system of government. For this reason the argument is that Islam does not pose any obstacle to democratization. Shahin ${ }^{33}$ for instance claim that Arab countries do have legacies of democracy, even though weak ones. 
Sustainable Democracy and the Paradox of the Arab Spring

\section{Egypt and the Arab Spring}

The 1980s and 1990s witnessed waves of global democratization. The nature of the movement differs from country to country. While some autocratic regimes acceded to elections, some others departed absconded from the country and some others resisted. The story was the same in the Arab world. Alam quoting Ahmed ${ }^{34}$ observed that it is usually the repressive policies of government and the total absence of freedom to pursue normal political activities that tend to drive religious and other political groups to radicalism and violent method of change. Alam quoting Hafez ${ }^{35}$ considered the lack of political democracy as the major cause for the development of religious fundamentalism, particularly in the muslim world.

Sorenson ${ }^{36}$ also noted that as in 2009 Freedom House ratings indicated that the march to democracy in the Arab countries was moving backwards. He further observed that as limited freedom in some Arab countries vanished regimes increasingly feared the rising tides of discontent fed by stagnant economies, growing corruption, regime misbehaviour and the rise of islamist movements that increasingly wanted to enter the political system through popular elections. Sorenson ${ }^{37}$ went on to claim that unaccountable Arab regimes dreaded that street protests enabled by a growing adoption of social communications media would quickly spread to their own countries. For this reason some Arab countries rolled back their limited democracy, censoring or suspending news media, banning islamists from parliament, and jailing those whose political activism went beyond regime redlines. Coppedge ${ }^{38}$ aptly observed that the legitimacy formulae of the Arab rulers have rarely rested on democratic principles.

It was therefore no surprise when by early 2011, mass public protests swept much of the Arab world. In Tunisia the protesters demanded for the restoration of the country's suspended constitution. President Ben Ali's Tunisia thus became the first Arab dictator to witness mass protest and the subsequent collapse of the regime. President Ben Ali in the face of the protest abdicated the throne. The protest spread to Egypt and other Arab countries. In Egypt the slogan no longer was "Islam is the solution" but Tunisia is the solution". The discontent over Hosni Mubarak regime spread beyond Cairo's Tahrir square to other Egyptian cities. As the revolt escalated Egyptian senior army officers joined the protesters in support. The Egyptian revolution was more or less nonviolent. The protesters refused to be provoked by thugs, they were able to coordinate their demands, and organize without any central leadership.

The discipline exhibited by the protesters during the revolt and the subsequent wide-ranging debates on how to shape the country nonetheless gave the impression that Egypt was about to chart a new course. Developments in post Arab spring Egypt has demystified the so called democratic awakening or the Arab spring. The experience of democratization in other chimes explains the distinguishing features of individual countries. It does at the same instance highlight such instances and conditions that will strongly influence the failure or success of democratization. Unfortunately the large scale uprising against autocratic regimes in the Arab world gave the impression of an Arab democratic awakening. This supposition was reinforced by the ouster of Presidents Ben Ali of Tunisia and Mubarak of Egypt from office. Furthermore the constitutional reforms that followed soon after convinced some pessimist of a new era in the Arab world.

It is however of interest to note some major factors that gave vent to the anger of the people and subsequently to the populist protest. Egypt is a classic example. According to Andrson ${ }^{39}$ Mubarak's government deteriorating ability to provide basic services and seeming indifference to widespread unemployment and poverty alienated tens of millions of Egyptians. A feeling that was 


\section{Etemike Laz}

exacerbated by growing conspicuous consumption among business elite connected to Mubarak's son Gamal.

Alterman ${ }^{40}$ argued that Islam did not have a significant role to play in the protests. The Muslim Brotherhood also did not engage in the events and consciously limited their activities. Migranyan ${ }^{41}$ added that in his view the Muslim Brotherhood was being "sophisticated and smart" in calculating the right time to enter the political arena if and when the army would lose its power. Alterman ${ }^{42}$ however, did speculate that Islam could have a larger role to play in the long term, although this was not an Islamic revolution.

His prediction came true because Muhammed Morsi a member of the Muslim Brotherhood become Egypt's President. The Muslim Brotherhood was thus the beneficiary of the revolution. In the long run the Muslim Brotherhood government failed to accommodate the moderate elements of the Muslim Brothers and the progressive parties. President Morsi was accused of presiding over a paranoid and sectarian administration in which Islamist loyalists occupied strategic positions in the administration and the judiciary. President Morsi produced a skewed constitution that favoured the Brotherhood. Consequently, while Egypt democratic revolution was made on the streets; it was lost on the altar of religious fanaticism. President Morsi,s government saw the emergence of the forms of rule that drew strength from patronage, as was common in the Arab world, hence thwarting democratic transformation. President Morsi's fallout with the Islamic moderates and the opposition allowed the Egyptian military to once again climb the mantle of leadership.

The role of the military in the Arab uprising differs from regime to regime. In Egypt the military were reluctant to intervene against protesters. Erdogan ${ }^{43}$ provide two interpretations for this; first, he opine that the military in Egypt enjoys a certain degree of autonomy from the central civilian leadership, secondly, it considered its survival in the face of a popular uprising and mass discontent with the regime. Hence the military's neutrality, while in some cases siding with the protesters. The posture adopted by the military during the uprising thus shaped the outcome of the uprising. It is important to recall that since the 50's and 60's the military had played a key role in regime change or survival. Despite the seemingly claim by the Egyptian military of supporting democratization, there has been the challenge of subjecting the military to democratic civilian control. This according to Erdogan ${ }^{44}$ is because of its strong institutional interests in maintaining its political influence and lucrative enterprises.

The Egyptian military is widely respected by the general populace and deeply interwoven into the domestic economy. The military has been a part of the history of governance in Egypt. They had in 1951 ousted the post-imperial government. Thereafter the military has been involved in Egyptian politics. After the revolution the transition was managed by the Supreme Council of the Armed Forces(SCAF) composed of senior military officers who sought to protect its economic and political interest. SCAF further continued to interfere in many aspect of the transition. For instance there was delay in holding elections and in producing a constitution ${ }^{45}$. The "coup" over President Morsi's government revived essentially elements of the Mubarak era, such as the secret police, generals were back in charge of provincial governments, a ban on the Muslim Brotherhood as a terrorist organization and a clamp-down on demonstrations. el-Sisi and the army violently crushed the Muslim Brotherhood and the liberal secular opposition. More than 2,500 civilians were killed; with about 16,000 persons jailed. The new constitution enshrined the power and privileges of the armed forces while at the same time curtailing the freedom of assembly and expression.

The elections that followed in Egypt was conducted under tight security and the military strong man Gen el Sisi, soldier turn civilian, who ousted President Morsi of the Muslim Brotherhood contested and won. An election in which, foreign observers adjudged to fall short of international standards of democracy. As expected the Muslim Brotherhood and mot Egyptians boycotted the election. Only about 47 percent out of 54 million eligible voters voted in an election in which officials extended voting 
from two days to three with threat to those who fail to vote. Those who voted did so not because they find the candidates suitable but because they prefer it than the Muslim Brotherhood and needed stability. Abdel Fattah el-Sisi had the loyalty of the army and a subservient press behind him. Egyptians again are back to a security state they thought they had overthrown with the departure of Hosni Mubarak. The new constitution simple restored the old order. The election was a sham prospectus to secure benevolent despotism.

\section{Conclusion}

Decades of political control, stagnation and top-down control across the Arab countries fuelled the uprising generally referred to as the Arab Spring. Though the agitations were directed towards a call for democratization, the outcome of the revolts took different trajectories. While protesters united around the desire to topple repressive authoritarian regimes, they also differed about what should come next. For instance, in Egypt the Muslim Brotherhood prevailed. The election that preceded the protest gave a false hope that democratization would follow.

Despite the fact that democracy is preferable by majority of the Arab opinions, the persistence of authoritarianism and anti-democratic forces across the Arab world for decades produced a class that manipulate religion and patronage to hold on to power. Hence the resistance of regimes and their entrenched economic, political and military collaborators formed barriers to democratization in the Arab world. The question of fundamentalism existing in the various Islamic sects has contributed in compounding the quest for democracy in the Arab countries. In Egypt the Islamic group the Muslim Brotherhood illustrate how Islamist group make political gains. The Muslim Brotherhood regime in Egypt unfortunately failed to create a robust political society in which non Islamist can secure the kind of organized popular support that Islamist command ${ }^{46}$. Brumberg ${ }^{47}$ rightly observed that the hybrid regimes created circumstances under which free elections could well make illiberal Islamist the dominant voice, leaving democrats caught between ruling autocrats and Islamist or military would-be autocrats.

It is for this reason that Egypt democratic process need to address the twin problem of extreme Islamic fundamentalism and politicized military elite. Egypt has been struggling with the long shadow of military rule and a deep schism existing between secular groups and the Muslim Brotherhood. As a result of the conflicting desires of the various interest groups most Arab States are unable to build a viable independent political structure. The lack of a viable independent structure has thus made it possible for both the military, monarchies and extremist to control political power. Constructing these democratic structures and institutions has encountered serious opposition from various quarters. For instance, the military often is wary of limits on its authority, and religious groups may fear that strong democratic institutions may limit religious expression ${ }^{48}$

Religion derives its influence more from faith than from democratic choice. As a result the monarchies, extremist, military and other Islamic organizations gain influence by having religion designated as the official state religion. Their aversion to democracy may not be unconnected with a fear of a loss of political power to secular institutions. The declaration by some Arab States to be republic is a mere sham. Despite their claim to secularism they are a particular theocratic form of government, for which some advocate have described, as a compromise between a purely Islamic caliphate and a secular nationalism and republicanism. The panel code of the state was required to be compactable with the law of shariah. The identified barriers to democratization in the Arab world are so entrenched in the Arab state and society that the possibility of supplanting them with democracy is 


\section{Etemike Laz}

going to be a herculean task. The exceptionalism of these factors created the tendency to be pessimistic about the future of democracy in the Arab world. In the light of the Arab spring and Egypt's experience, the claim that Islam does not pose any obstacle to democratization cannot be sustained.

\section{Notes}

${ }^{1}$ D.S Sorenson, Transitions in the Arab World:s pring or Fail/ strategic Studies Quarterly (2011). Retrived on 06/27/2012 from www.all.af.mi/au/ssj/2011fall/sorenson.pdf.

${ }^{2}$ D. Clifford. May, Democratic Awakening in Arab States not guaranteed (2011). Retrieved on 07/13/2013 from www.koreatimes.cokrl/../160-83926.html

${ }^{3}$ G.M Rubeiz, the Impact of Arab Awakening on Political Islam, Oil and Palestine. (2011) Retrieved on

11/12/2012. From www.english.globalarabnetwork.com/.../-the-impact-arab-awakening-on-political-lslam-oiland-palestine-html

${ }^{4}$ Stephen Mcknerney cited in Persinger S.S. the Tipping Point: Transitions to Democracy in Latin America and the Middle East. A report from the Symposium hosted by the University of Notre Dame. (2012) Retrieved On 03/07/2012 from www.kellogg.nd.edu/about/tipping\%20point.pdf

${ }^{5}$ Hazrat Mirza Tahir Ahmed Khalifatul Masih IV Shariah: relationship between religion and politics in lslam. A speech delivered at the inter religious consults, surname on $3^{\text {rd }}$ june published by lslam international publication LTD. (1slambad UK:Rageem Press 1991). Retrieved on 02/08/2013 from www.alslam.org/books/shariah/relationship/between/religion/politics.pdf

${ }^{6}$ D.S Sorenson, (2011)

${ }^{7} \mathrm{Ibid}$

${ }^{8}$ Hazrat Mirza Tahir Ahmed Khalifatul Masih IV (1991)

${ }^{9}$ Ogbonnage, I.K and Ofoeze, H.G.A (1994) Theoretical and Practical Problem of Democratisation in Africa: an Introduction in Omo-Omoruyi et al (Eds) Democratisation in Africa. Nigerian perspective vol 1. Nigeria:Hima Hima.

${ }^{10}$ S Oyovbaire, (Ed) Democratic Experiment in Nigeria: Interpretative Essays. (Benin City: Omega Publishers LTD1987).

${ }^{11}$ P.Burnell, Lessons of experience in international Democrcay support: implications for Supporting Democratic change in North Africa (2011). Retrieved on 11/12/2012 from www.wider.unu.edu/publication/workingpaper/2011/en-Gb/wp2011-084/html

${ }^{12}$ R. Dahi, Polyarcchy: Participation and opposition. New Haven:Yale University 1971.

${ }^{13}$ O. Nwokeji, A Historical and Theoretical Diagnosis of African Democratic Delusions. In Omo Omoruyi (Eds)Democratisation in Africa: Nigeria perspective 1. Nigeria: Hima Hima 1994, P.34

${ }^{14}$ O. Onoge, The Democratic Imperative in Africa. (Nigeria:Africa Centre for Democratic Governance 1998 p, 12).

${ }^{15}$ P. Burnell, (2011)

${ }^{16}$ Rou cited in Heywood, A(2004) Politics. Palgrave: New York 2th Edition.

${ }^{17}$ A. Heywood, Politics. (Palgrave: New York 2th Edition 2004). P.74

${ }^{18}$ Ibid.

${ }^{19}$ Ibid. 75

${ }^{20}$ O.P Gauba, An Introduction to political theory. (Macmillan: Delhi $4^{\text {th }}$ Edition 2004 p, 424).

${ }^{21}$ Ibid p, 425

${ }^{22}$ Ibid .p, 427

${ }^{23}$ O. Onoge, (1998)

${ }^{24}$ Z. Brzezinki, the global political awakening. The New York Times: December 16, 2008. Retrieved on 02/10/2011 from http/::www.nytimes.com/2008/12/16/opinion/16/ht-Ye-brzenzinski-html

${ }^{25}$ See Sorenson, D.S (2011)

${ }^{26}$ Ibid.

${ }^{27}$ Coppedge, $\mathrm{M}$ cited in Persinger S.S. (2012) the Tipping Point: Transitions to Democracy in Latin America and the Middle East. A report from the Symposium hosted by the University of Notre Dame. Retrieved On 03/07/2012 from www.kellogg.nd.edu/about/tipping\%20point.pdf

${ }^{28}$ Ibid. 
${ }^{29}$ Rubeiz, G.M (2011)

${ }^{30}$ See Sorenson, D.S (2011)

${ }^{31}$ Ibid

32 Ibid quoting Asef Bayat, 2007:187)

${ }^{33}$ E.Sahin, cited in Persinger S.S. the Tipping Point: Transitions to Democracy in Latin America and the Middle East. A report from the Symposium hosted by the University of Notre Dame(2012). Retrieved On 03/07/2012 from www.kellogg.nd.edu/about/tipping\%20point.pdf

${ }^{34}$ A. Alam Political management of Islamic Fundamentalism: Aview from India. Ethnicities 7(1):30-60(2007). Retrieved on 04/23/2013 from http://etn.sagepub.com/doi:10:1177/1468796807073916

35 Ibid quoting Hafez, 2004)

${ }^{36}$ See Sorenson, D.S (2011)

${ }^{37}$ Ibid

${ }^{38}$ M.Coppedge, cited in Persinger S.S. (2012)

${ }^{39}$ L. Anderson, Demystifying the Arab spring. Parsing the differences between Tunisia, Egypt, and Libya(2011). Retrieved on 06/27/2012 from www.ssresourcecentre.org/anderson.demystifying-the-arab-spring.pdf

${ }^{40}$ Alterman cited in Zikibayeva, A What does the Arab Spring mean for Russia, Central Asia, and the Caucasus? Center for Strategic and International Studies(2011). Retrieved on www.csis.org/.../110912zikibayeva.../what-does-arab-spring-means.pdf

${ }^{41}$ A. Migranyan, cited in Zikibayeva, A (2011) what does the arab spring mean for Russia, Central Asia, and the Caucasus? Center for Strategic and International Studies. Retrieved on www.csis.org/.../110912zikibayeva.../what-does-arab-spring-means.pdf

${ }^{42}$ Ibid.

${ }^{43}$ A. Erdogen, (2013) From the Collapse of Communism in Eastern Europe to the Arab Spring: Lessons for Democratic Transition. In the Alternative Turkish Journal of international Relations. 12/3.www.alternativejournal.net

${ }^{44}$ Ibid

${ }^{45}$ Mcknerney Stephen cited in Persinger S.S. (2012) the Tipping Point: Transitions to Democracy in Latin America and the Middle East. A report from the Symposium hosted by the University of Notre Dame. Retrieved On 03/07/2012 from www.kellogg.nd.edu/about/tipping\%20point.pdf

${ }^{46}$ D. Brumberg U.S.A Policy and the Arab World. Retrieved on 10/02/2012 from www.usip.org/.../U.S-policyand-the-arab-spring-brumberg (2011 p. 57)

47 Ibid.

${ }^{48}$ See Sorenson, D.S (2011) 